\title{
Peningkatan Kemampuan Administrasi Tender Pengadaan Barang/Jasa Pemerintah di Bidang Jasa Konstruksi
}

\author{
Zaenal Arifin, Soegianto, Diah Sulistiyani RS \\ Magister Hukum, Universitas Semarang, Indonesia \\ zaenal@usm.ac.id
}

Received: $25^{\text {th }}$ March 2020 | Accepted: 25 $5^{\text {th }}$ July 2020 | Publihsed: 20 ${ }^{\text {th }}$ August 2020

Key word:

Auction; procurement of government goods/services; contractor

Kata Kunci

lelang; pengadaan barang/jasa pemerintah; kontraktor

\section{Abstract}

The purpose of this community service is to improve the ability to hold tenders for goods/ service providers in the construction service sector. The Association of National Construction Entrepreneurs (Gapensi) Semarang City as a community service partner is 348 people divided into 7 classifications. Some of the reasons for goods and service providers who are members of Gapensi fail to win tenders are 1) a lack of understanding of the development of existing regulations related to the procurement of goods/ services that often change; 2) administrative errors in completing the auction for the procurement of goods and services; 3$)$ Providers of goods/services are usually left to one administrative person so that the owner of the business entity never knows the procedure or mechanism and completeness of the procurement of government goods/services. The method used in this service is the socialization of the latest procurement of goods/ services and training in the governance of government procurement of goods/ services. The result of this service is that Gapensi members know the good governance of government procurement of goods and services and are able to practice in tenders.

\section{Abstrak}

Tujuan dari pengabdian masyarakat ini adalah untuk meningkatkan kemampuan penyelenggaraan tender bagi penyedia barang/ jasa di bidang jasa konstruksi. Gabungan Pengusaha Konstruksi Nasional (Gapensi) Kota Semarang sebagai mitra pengabdian masyarakat berjumlah 348 orang yang terbagi dalam 7 klasifikasi. Beberapa penyebab penyedia barang dan jasa yang tergabung dalam Gapensi gagal memenangkan tender tender adalah 1) kurangnya pemahaman terhadap perkembangan regulasi yang ada terkait pengadaan barang/ jasa yang sering berubah; 2) kesalahan administrasi dalam kelengkapan lelang pengadaan barang dan jasa; 3) Penyedia barang/ jasa biasanya diserahkan kepada satu orang administrasi sehingga pemilik badan usaha tidak pernah mengetahui prosedur atau mekanisme dan kelengkapan pengadaan barang/ jasa pemerintah. Metode yang digunakan dalam pengabdian ini adalah sosialisasi tentang pengadaan barang/ jasa terkini dan pelatihan tata kelola pengadaan barang/ jasa pemerintah. Hasil pengabdian ini adalah anggota Gapensi mengetahui tata kelola pengadaan barang dan jasa pemerintah dengan baik dan mampu mempraktikkan dalam tender. 


\section{PENDAHULUAN}

Seiring dengan reformasi yang bergulir, muncul harapan agar dalam pelaksanan belanja yang dibiayai oleh APBN/APBD dapat dilaksanakan secara efektif dan efisien dengan mengutamakan penerapan prinsip-prisip persaingan usaha yang sehat, transparan, terbuka dan berlaku adil bagi semua pihak. Serlain lingkup dan cakupan pengadaan barang/jasa pemerintah yang luas, bersifat lintas institusi dan lintas sektor, juga berdampak baik pengembangan usaha kecil, peningkatan produksi dalam negeri, dan pengembangan iklim dan dunia usaha pada umumnya (Arsyad, 2018).

Pengadaan barang dan jasa tidak hanya diatur dalam satu peraturan saja. Hal ini karena pengadaan barang dan jasa merupakan proses yang panjang, dari proses perencanaan penganggaran, prosees pengelolan anggaran, proses pengadaan barang dengan anggaran yang sudah direncanakan, dan pertanggungjwaban hasil dari pengadaan barang dan jasa secara adminitrasi dan teknis (Faisal dkk., 2017).

Peraturan yang mengatur tentang pengadaan barang/jasa pemerintah yaitu Peraturan Presiden (Perpres) Nomor 54 Tahun 2010 tentang Pengadaan Barang/Jasa Pemerintah sebagaimana telah mengalami beberapa kali perubahan, dan masih banyak terdapat kekurangan dan belum menampung perkembangan kebutuhan Pemerintah mengenai pengaturan atas Pengadaan Barang/Jasa yang baik, pemerintah memandang perlu menetapkan Peraturan Presiden tentang Pengadaan Barang/Jasa Pemerintah yang baru sebagai jawaban adanya tuntutan reformasi di pengadaan barang/jasa pemerintah maka Pemerintah menerbitkan Peraturan Presiden Nomor 16 tahun 2018 tentang Pengadaan Barang/Jasa Pemerintah sebagai revisi atas Perpres No 54 Tahun 2010 tentang Pengadaan Barang/Jasa Pemerintah beserta perubahannya.

Peraturan Presiden No 16 Tahun 2018 ini memiliki 15 bab dengan 98 pasal, lebih sederhana jika dibandingkan dengan Peraturan Presiden Nomor 54 tahun 2010 beserta perubahannya. Perpres No 16 Tahun 2018 disamping jumlah pasalnya lebih sedikit juga menghilangkan bagian penjelasan dan menggantinya dengan penjelasan norma-norma pengadaan. Revisi pengaturan pengadaan barang/jasa pemerintah ini diharapkan dapat memperbaiki proses pengadaan barang/jasa pemerintah untuk menghindari adanya malpraktik ataupun kecurangan dalam pelaksanaan pengadaan barang/jasa pemerintah.

Sebagai upaya untuk memenuhi hak dan kebutuhan pelayanan umum yang 
layak diperlukan landasan hukum yang kokoh dalam proses pengadaan barang/jasa. Pengadaan barang/jasa pemerintah harus menjamin kepastian hukum dan memberikan perlindungan bagi setiap warga negara dan masyarakat dari penyalahgunaan wewenang di dalam penyelenggaraan pengadaan barang/jasa guna menciptakan iklim pengadaan barang/jasa yang kondusif (Susila, 2012).

Perubahan yang ada dalam Perpres No 16 Tahun 2018 ini adalah pekerjaan konsultan yang naik menjadi Rp. 100.000.000,00 (seratus juta rupiah), dan adanya terobosan agar pengadaan barang/jasa pemerintah bisa lebih cepat dengan Unit Layanan Pengadaan (ULP) yang berubah menjadi Unit Kerja Pengadaan Barang/Jasa (UKPBJ), sebuah unit organisasi yang bersifat permanen yang diantaranya memiliki peran yntuk melakukan pembinaan, pemilihan penyedia dan pengelolaan sistem informasi. Pengertian pengadaan barang/jasa pemerintah juga mengalami perubahan, menurut Perpres No 16 Tahun 2018 pengertian Pengadaan Barang/Jasa Pemerintah selanjutnya disebut dengan Pengadaan Barang/Jasa adalah kegiatan pengadaan barang/jasa oleh Kementerian/Lembaga/Perangkat Daerah yang dibiayai oleh APBN/APBD yang prosesnya dimulai dari identifikasi kebutuhan, sampai dengan serah terima hasil pekerjaan. Ada perubahan penyebutan dari "Institusi" yang disederhanakan menjadi "Lembaga" sehingga tidak diperlukan lagi penyebutan K/L. Perubahan Satuan Kerja Perangkat Daerah (SKPD) menjadi Perangkat Daerah adalah akibat dari penyesuaian istilah SKPD menjadi Perangkat Daerah (Undang-Undang Nomor 9 Tahun 2015 tentang Pemerintah Daerah, 2015).

Adanya perubahan pengaturan pengadaan barang/jasa pemerintah tersebut tentunya akan menimbulkan aturan baru terutama dalam administrasi tender pengadaan barang/jasa pemerintah. Baik pengguna barang maupun penyedia barang/jasa harus dapat mempunyai pengetahuan dan menguasai materi yang ada dalam aturan baru tersebut.

Ketidaktahuan atau terbatasnya pemahaman aturan baru tersebut dapat menggugurkan penyedia barang/jasa dalam mengikuti tender pengadaan barang/jasa pemerintah. Berkenaan dengan hal tersebut di atas itu juga terjadi di kota Semarang dalam hal ini oleh penyedia barang/jasa di bidang konstruksi yang menjadi anggota Gapensi kota Semarang. Kesalahan dan permasalahan yang ada dalam tender tersebut karena ketidaktahuan dengan perkembangan regulasi yang ada berkaitan dengan pengadaan barang/ jasa 
pemerintah.

Jasa konstruksi adalah layanan jasa konsultansi perencanaan pekerjaan konstruksi, layanan jasa pelaksanaan pekerjaan konstruksi, dan layanan jasa konsultansi pengawasan pekerjaan konstruksi; Pekerjaan konstruksi adalah keseluruhan atau sebagian rangkaian kegiatan perencanaan dan/atau pelaksanaan beserta pengawasan yang mencakup pekerjaan arsitektural, sipil, mekanikal, elektrikal, dan tata lingkungan masing-masing beserta kelengkapannya, untuk mewujudkan suatu bangunan atau bentuk fisik lain (Undang-Undang Nomor 2 Tahun 2017 tentang Jasa Konstruksi, 2017).

Di kota Semarang terdapat 348 penyedia barang dan jasa yang terbagi dalam 7 klasifikasi yang berdasarkan Peraturan LPJK No 2 Tahun 2013 tanggal 15 Januari 2013 membagi kualifikasi usaha jasa kontraktor sebagai berikut :

1. Kualifikasi B2 mempunyai kekayaan bersih > Rp.50 milyar,

2. Kualifikasi B1 mempunyai kekayaan bersih Rp 10 milyar sd Rp50 milyar,

3. Kualifikasi M2 mempunyai kekayaan bersih Rp 2 milyar sd Rp 10 milyar

4. Kualifikasi M1 mempunyai kekayaan bersih Rp.500 jt sd Rp 2 milyar,

5. Kualifikasi K3 mempunyai kekayaan bersih Rp. 350 juta sd Rp 500 juta,
6. Kualifikasi K2 mempunyai kekayaan bersih Rp 50 juta sd Rp 200 juta,

7. Kualifikasi K1 mempunyai kekayaan bersih Rp 50 juta sd 200 juta.

Adapun jumlah penyedia barang yang sebaran kualifikasi badan usahanya sebagai berikut: kualifikasi besar 2 sebanyak $0,3 \%$ atau 1 penyedia barang dan jasa, besar 1 sebanyak $3.4 \%$ atau 12 penyedia barang dan jasa, menengah 2 sebanyak $5.7 \%$ atau 20 penyedia barang dan jasa, menengah 1 sebanyak $13.2 \%$ atau 46 penyedia barang dan jasa, kecil 3 sebanyak $18.7 \%$ atau 65 penyedia barang dan jasa, kecil 23 sebanyak $6.6 \%$ atau 1 penyedia barang dan jasa, kecil 1 sebanyak $52.0 \%$ atau 181 penyedia barang dan jasa. Dibawah ini digambarkan sebaran penyedia barang jasa konstruksi yang ada di Kota Semarang yang telah terdaftar pada BPC Gapensi Kota Semarang Tahun 2019 (Arifin dkk., 2020).

Grafik 1. Sebaran Kualifikasi Penyedia Barang dan Jasa

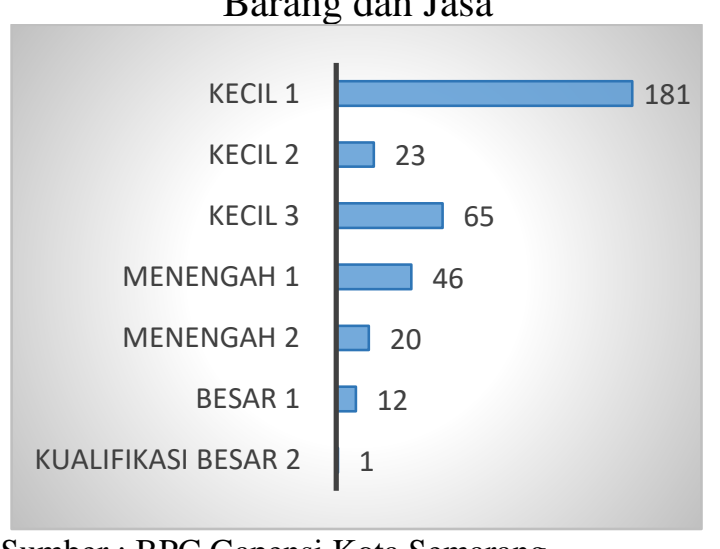

Sumber : BPC Gapensi Kota Semarang

Praktik pengadaan barang/jasa 
pemerintah di Kota Semarang sudah menggunakan sistem on line sehingga kelengkapan administrasi harus benarbenar sesuai dengan ketentuan peraturan yang telah ditetapkan oleh peraturan perundang-undangan dan panitia pengadaan barang dan jasa. Kesalahan format dan kelengkapan akan dapat menggagalkan penyedia barang dan jasa untuk dapat meneruskan bahakan sampai menang dalam pengadaan barang/jasa yang diselenggarakan oleh Pemerintah Kota Semarang.

Praktek pengadaan barang/jasa yang ada di Kota Semarang sudah menggunakan sistem on line sehingga kelengkapan administrasi harus benar-benar sesuai dengan ketentuan peraturan yang telah ditetapkan oleh peraturan perundangundangan dan panitia pengadaan barang dan jasa. Kesalahan format dan kelengkapan akan dapat menggagalkan penyedia barang dan jasa untuk dapat meneruskan bahakan sampai menang dalam pengadaan barang/jasa yang diselenggarakan oleh Pemerintah Kota Semarang.

Berdasarkan hasil wawancara yang dilakukan tim pengabdi terhadap calon mitra pengabdian, ada beberapa penyebab penyedia barang dan jasa di bidang konstruksi gagal dalam memenangkan tender adalah: kesalahan administrasi kelengkapan lelang pengadaan barang/jasa sebanyak $48 \%$; kekurang pahaman akan perkembangan regulasi yang ada berkaitan dengan pengadaan barang/jasa yang sering berubah sebanyak sebanyak $24 \%$, penyedia barang/jasa hanya meyerahkan prosedur dan mekanisme tender kepada satu tenaga administrasi sebanyak $20 \%$ dan sebanyak $8 \%$ menjawab lain lain.

Grafik 2. Persentase Faktor Penyebab Kegagalan Tender

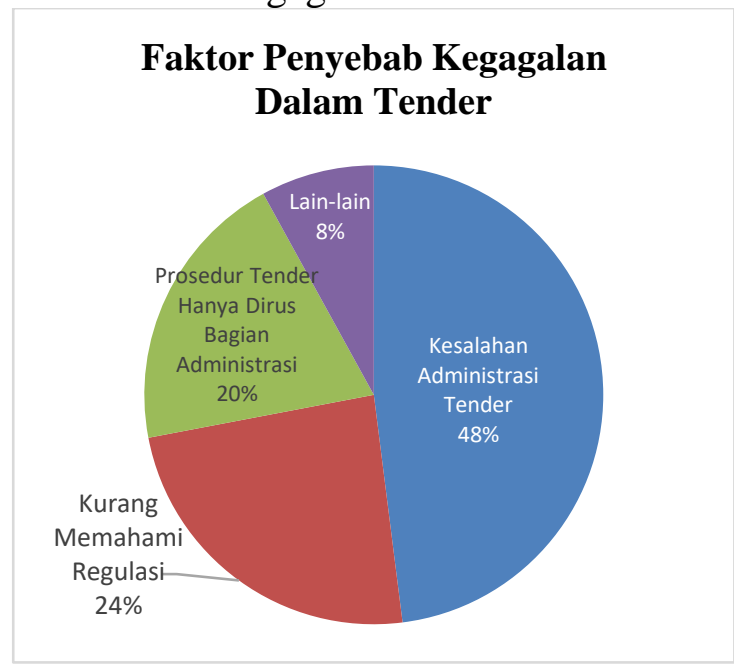

Sumber : Data Primer, 2020 (Diolah)

Berkenaan dengan analisis situasi diatas maka dapat di simpulkan bahwa permasalahan yang dihadapi oleh mitra adalah sebagai berikut:

a. Pengetahuan dan pemahaman mitra akan regulasi tentang pengadaan barang/jasa pemerintah masih sangat kurang, penyebabnya adalah mereka tidak up date akan regulasi tentang pengadaan barang/ jasa pemerintah; 
Tata kelola administrasi penyedia barang dan jasa masih sangat kurang, penyebanya adalah penyedia barang/jasa terlalu menggantungkan atau menunjuk salah satu karyawannya yang mengurusi sehingga sangat berisiko dalam pelaksanaan tender pengadaan barang/jasa pemerintah secara berkelanjutan.

\section{METODE}

Permasalahan dalam pengabdian kepada masyarakat yang disepakati antara Tim Pengabdian Kepada Masyarakat Magister Hukum Universitas Semarang dengan mitra yaitu BPC Gapensi Kota Semarang adalah (1) permasalahan pengetahuan dan pemahaman mitra akan regulasi tentang pengadaan barang/jasa pemerintah (2) tata kelola administrasi penyedia barang/jasa pemerintah.

Solusi yang ditawarkan dalam permasalahan pengetahuan dan pemahaman mitra akan regulasi pengadaan barang/jasa pemerntah adalah:

a. Sosialisasi akan peraturan pengadaan barang/jasa pemerintah yang terbaru yaitu : Peraturan Presiden Nomor 16 tahun 2018 tentang Pengadaan Barang/Jasa Pemerintah.

Metode pelaksanaan kegiatan sosialisasi yang akan diselenggarakan tahapannya adalah sebagai berikut:
- Tahap Persiapan: tahapan ini adalah melakukan perencanaan jadwal pelaksanaan, menyusun Kerangka acuan kerja, menyusun kuesioner pretest dan post test yang digunakan untuk megukur pengetahuan peserta, menyusun undangan, menyusun materi sosialisasi, dan menyiapkan kelengkapan sosialisasi.

- Tahap Pelaksanaan, pada tahap ini, dilakukan sosialisasi dengan menghadirkan para penyedia barang/jasa yang terdaftar sebagai anggota BPC Gapensi Kota Semarang, yang diawali dengan pretest dan diakhir sosialisasi dilakukan post test.

- Tahap Evaluasi, pada tahap ini akan dilakukan evaluasi pelaksanaan kegiatan sosialisasi dan mengukur ketercapaian target kegiatan yaitu tingkat pemahaman peserta.

b. Pelatihan penyusunan dokumen barang/jasa pemerintah. Metode pelaksanaan kegiatan penyusunan dokumen pengadaan barang dan jasa ini ini adalah:

- Tahap persiapan: tahapan ini adalah melakukan perencanaan jadwal pelaksanaan, menyusun kerangka acuan kerja, menyusun kuesioner pretest dan post test yang digunakan untuk mengukur evaluasi kegiatan, 
menyusun undangan, menyusun materi pelatihan, dan menyiapkan kelengkapan pelatihan.

- Tahap Pelaksanaan, pada tahap ini, dilakukan pelatihan dengan cara pemberian materi dan sekaligus peserta melakukan praktek penyusunan dokumen pengadaan barang dan jasa.

- Tahap Evaluasi, pada tahap ini akan dilakukan evaluasi pelaksanaan kegiatan Pelatihan dan mengukur ketercapaian target kegiatan.

Solusi yang ditawarkan dalam tata kelola administrasi adalah penyusunan modul atau buku panduan tata kelola administrasi pengadaan barang/ jasa pemerintah. Metode pelaksanaan penyusunan modul atau buku panduan tata kelola administrasi pengadaan barang/jasa pemerintah adalah sebagai berikut:

1. Mengidentifikasi seluruh kebutuhan dokumen pengadaan barang/jasa pemerintah;

2. menyusun kerangka modul atau buku panduan tata kelola administrasi pengadaan barang/jasa pemerintah;

3. mengisi konten modul atau buku panduan tata kelola administrasi pengadaan barang/jasa pemerintah;

4. melakukan telaah modul atau buku panduan tata kelola administrasi pengadaan barang/jasa pemerintah;
5. melakukan penjilidan buku panduan tata kelola administrasi pengadaan barang/jasa pemerintah;

6. melakukan sosialisasi modul atau buku panduan tata kelola administrasi pengadaan barang/jasa pemerintah.

\section{HASIL}

Gambaran umum pengadaan barang dan jasa pemerintah di Indonesia khususnya di Kabupaten Penajam Paser Utara masih dirasa tidak efisien dan transparan, karena adanya beberapa permasalahan dalam pelaksanaan pengadaan barang dan jasa, yaitu: Pertama, kapasitas manajemen dan kelembagaan yakni kurangnya kapasitas dan integritas sumber daya manusia untuk mengelola pengadaan barang dan jasa (Hidayat, 2015). Penelitian tersebut dapat menunjukkan bahwa kualitas sumber daya manusia di bidang pengadaan barang/jasa pemerintah masih rendah.

Terhadap pengaturan pengadaan barang/jasa pemerintah maka diperlukan pengaturan hukum yang jelas dan mampu memenuhi perkembangan pasar, sehingga prinsip kepastian hukum diperoleh para pihak yang terlibat dalam proses pengadaan tersebut (Listiyanto, 2012). Hal ${ }^{\mathrm{i}}$ ni merupakan salah satu faktor mengapa pengaturan pengadaan barang/jasa sering berubah disamping pengaturan pengadaan 
barang/jasa pemerintah harus selalu mengikuti perkembangan jaman. Sehingga perlu suatu pencapaian agar dapat mengikuti perkembangan pengaturan tentang pengadaan barang/jasa pemerintah. Kegitan sosialisasi pengaturan pengadaan barang/jasa juga sebagai salah satu upaya dalam meningkatkan sumber daya manusia.

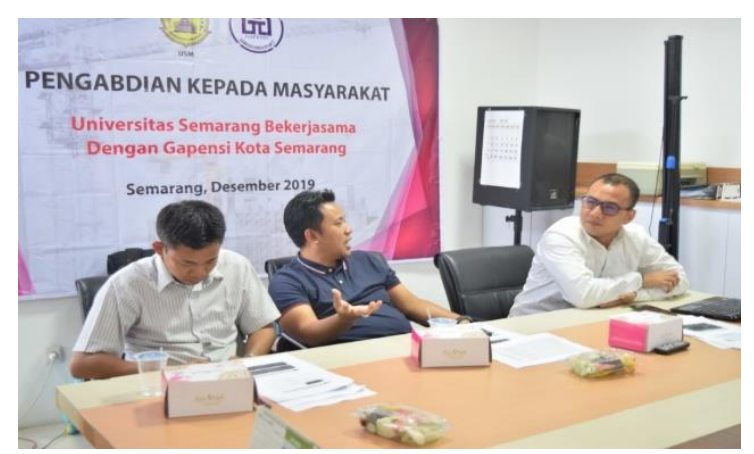

Gambar 1. Dialog interaktif narasumber dengan peserta

Hasil luaran yang dicapai sesuai dengan target luaran yaitu berupa modul yang berisi panduan tata kelola administrasi pengadaan barang/jasa pemerintah dan publikasi di media massa. Permasalahan yang dihadapi mitra berupa pengetahuan dan pemahaman akan regulasi tentang pengadaan barang/jasa pemerintah yang masih kurang diakibatkannya sering tejadi peraturan yang berubah-ubah. Terakhir pengaturan yang baru berupa Undang-Undang No 2 Tahun 2017 tentang Jasa Konstruksi dan Peraturan Presiden No 16 Tahun 2018 tentang Pengadaan Barang/Jasa.

\section{PEMBAHASAN}

Solusi yang dilaksanakan atas permasalahan mitra tersebut yaitu dengan mengadakan sosialisasi mengenai aturan terbaru yaitu Undang-Undang N0 2 Tahun 2017 tentang Jasa Konstruksi dan Peraturan Presiden No 16 Tahun 2018 tentang Pengadaan Barang/Jasa dan berupa pelatihan penyusunan dokumen barang/jasa pemerintah. Sosialisasi diberikan kepada anggota Gapensi yang mengirimkan anggotanya untuk mengikuti kegiatan tersebut. Anggota Gapensi yang mengikuti kegiatan sosialisai dan pelatihan penyusunan dokumen pengadaan barang/jasa pemerintah berpartisipasi aktif dalam pelaksanaan kegiatan tersebut. Peserta pelatihan juga aktif melakukan tanya jawab dan memberikan masukan terkait dengan materi yang nanti akan disusun berupa modul panduan tata kelola administrasi pegadaan barang/jasa pemerintah.

Pelaksanaan pengadaan barang/jasa melalaui e-katalog semakin kuat setelah terbitnya Peraturan Presiden Nomor 16 Tahun 2018 tentang Pengadaan Barang/Jasa Pemerintah. Pasal 50 ayat (5), bahwa pelaksanaan e-purchasing wajib dilakukan untuk barang/jasa yang menyangkut pemenuhan kebutuhan nasional dan/atau strategis yang ditetapkan oleh menteri, kepala lembaga, atau kepala 
daerah. Oleh karena itu, untuk barang/jasa yang diluar kriteria pemenuhan kebutuhan nasional dan/atau strategis, pengadaan barang/jasanya tidak wajib dilakukan melalui metode e-purchasing (Iqbal, 2020).

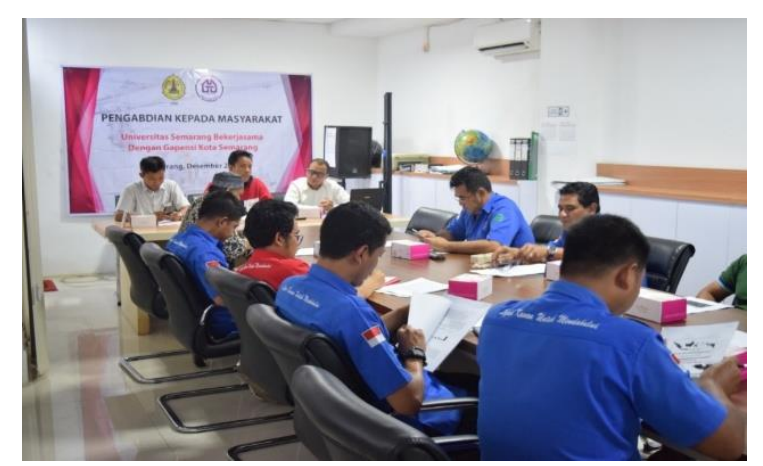

Gambar 2. Mitra pengabdian kepada masyarakat kuesioner

Perubahan pengaturan pengadaan barang/jasa pemerintah yang cukup signifikan adalah penagturan mengenai ekatalog dan e-tendering yang harus dapat diantispasi dan dipahami implementasinya oleh pelaksana penagdaan barang/jasa pemerintah.

Hasil yang dicapai dari kegiatan pengabdian ini adalah adanya peningkatan pemahamam dan pengetahuan tentang pengaturan pengadaan barang/jasa pemerintah di bidang konstruksi. Pertanyaaan kuesioner pertama dengan pertanyaan: Apakah anda pernah mengikuti sosialisasivperaturan perundang-undangan tentang pengadaan barang/jasa pemerintah (PJB) yang terbaru? Untuk jawaban sebelum dilaksanakanan pengabdian adalah sebanyak 14,3\% yang sudah mengikuti sosialisasi, sedangkan $83,7 \%$ belum pernah mengikuti sosialisasi. Jawaban yang diperoleh setelah dilakukan pengabdian adalah $100 \%$ menjawab sudah.

Kuesioner kedua dengan pertanyaan: Apakah anda tahu adanya perubahan peraturan PJB? Jawaban yang diperoleh sebelum dilaksanakan pengabdian adalah $78,6 \%$ menjawab sudah mengetahui, dan $21,4 \%$ dan jawaban yang diperoleh setelah dilakukan pengabdian adalah $100 \%$ sudah mengetahui adanya perubahan peraturan. Kuesioner ketiga dengan pertanyaan Apakah anda tahu tentang jenis peraturan PBJ? Sebanyak 42,8\% menjawab tidak tahu, sedangkan sisanya sebanyak 57,2\% menjawab sudah tahu. Jawaban yang diperoleh setelah dilakukan pengabdian adalah $100 \%$ menjawab sudah tahu.

Jawaban dari kuesioner keempat dengan pertanyaan: Apakah anda tahu perbedaan peraturan perundang-undangan PBJ yang baru dengan sebelumnya? Sebanyak 85,7\% menjawab tidak tahu, dan $14,3 \%$ menjawab sudah tahu. Setelah dilakukan pengabdian $100 \%$ menjawab sudah tahu. Kuesioner kelima dengan pertanyaan: Apakah anda tahu lembaga yang membentuk peraturan perundangundangan PBJ? Sebanyak 57,1\% 
menjawab sudah tahu dan sisanya $42,9 \%$ menjawab tidak tahu. Setelah dilakukan peningkatan pemahaman jawaban sudah tahu meningkat menjadi 100\%. Setelah dilaksanakan kegiatan pengabdian masyarakat ini tercatat ada peningkatan pemahamam sebesar 55,3\%.

\section{SIMPULAN}

Pelaksanaan pengabdian masyarakat beralan dengan baik, lancar dan terjadi dialog yang interaktif terkait dengan permasalahan yang dihadapi oleh mitra. Kesimpulan dari kegiatan pengabdian ini, adanya peningkatan pemahaman tentang pengaturan pengadaan barang/jasa pemerintah dan pemahaman tentang tata kelola administrasi penagdaan barang/jasa pemerintah. Adanya saran dan masukan terkait materi dari modul tata kelola adminitrasi pengadaan barang/jasa pemerintah membantu proses penyempurnaan modul.

\section{SARAN}

Saran dari hasil pengabdian ini adalah agar pemerintah selaku pembuat undang-undang dapat lebih mensosialisasikan aturan yang baru berupa bimbingan teknis tidak hanya pada panitia lelang tetapi juga kepada kontraktor/rekanan agar terjadi persamaan persepsi antar panitia tender dengan kontraktor/rekanan. Perlu adanya harmonisasi pengaturan pengadaan barang/jasa karena masih ditemukan aturan yang saling bertolak belakang. Bagi penyedia jasa perlu secara aktif mengikuti kegiatan sosialisasi atau bimbingan teknis terkait pelaksanaan Perpres No 16 Tahun 2018 tentang Pengadaan Barang/Jasa Pemerintah baik yang dilaksanakan pemerintah, organisasi profesi maupun lembaga terkait.

\section{UCAPAN TERIMA KASIH}

1. LPPM Universitas Semarang yang telah membiayai pengabdian kepada masyarakat ini.

2. Iswoyo, S.Pt., M.P selaku Ketua LPPM Universitas Semarang

3. Martono, selaku Ketua BPC Gapensi Kota Semarang, yang telah mengizinkan kegiatan pengabdian masyarakat di Gapensi Kota Semarang

4. Para anggota dan pengurus Gapensi Kota Semarang yang telah bersedia mengikuti dan berperan serta aktif dalam kegiatan pengabdian masyarakat ini.

\section{DAFTAR PUSTAKA}

Arifin, Z., Soegianto, S., \& Sulistyani, D. (2020). Perlindungan Hukum Perjanjian Kemitraan Pengadaan Barang/Jasa Pemerintah Pada 
Bidang Konstruksi. JURNAL USM

LAW REVIEW, 3(1), 59-76.

Arsyad, J. H. (2018). Sentralisasi birokrasi

pengadaan barang \& jasa

pemerintah. Sinar Grafika.

Faisal, N. I., Morasa, J., \& Mawikere, L.

M. (2017). Analisis Sistem

Pengadaan Barang dan Jasa

(Penunjung Langsung) pada di

Dinas Pekerjaan Umum dan

Penataan Ruang Kota Manado.

GOING CONCERN: JURNAL

RISET AKUNTANSI, 12(2).

Hidayat, R. (2015). Penerapan e-

Procurement Dalam Proses

Pengadaan Barang Dan Jasa

Pemerintah Guna Mendukung

Ketahanan Tata Pemerintahan

Daerah (Studi pada Unit Layanan

Pengadaan Barang dan Jasa

Pemerintah Kabupaten Penajam

Paser Utara Provinsi Kalimantan

Timur). Jurnal Ketahanan

Nasional, 21(2), 118-127.

https://doi.org/10.22146/jkn.10155
Iqbal, M. (2020). PENGARUH

Pelaksanaan E Katalog dalam

Pengadaan Barang/Jasa Pemerintah

Terhadap UMKM. JURNAL USM

LAW REVIEW, 3(1), 77-97.

Listiyanto, A. (2012). Pembaharuan

Regulasi Pengadaan Barang dan

Jasa Pemerintah. Jurnal Rechts

Vinding: Media Pembinaan Hukum

Nasional, 1(1), 113-133.

Susila, A. (2012). Mencermati Rancangan Undang-undang Pengadaan Barang dan Jasa Pemerintah. JURNAL

ADMINISTRASI DAN KEBIJAKAN

PUBLIK, 1(1), 39-54.

Undang-Undang Nomor 2 Tahun 2017

tentang Jasa Konstruksi. (2017).

Undang-Undang Nomor 9 Tahun 2015

tentang Pemerintah Daerah.

(2015). 